\title{
Megalapozó háttértanulmány a digitális eszközök tanulási célú használatának vizsgálatához az osztálytermi tevékenységek, a tanulási környezet és a tanulói összetétel kontextusában
}

\section{Bevezetés}

Jelen megalapozó háttértanulmány célja, hogy minél szélesebb körben feltárja és bemutassa azokat a hazai és nemzetközi kutatásokat, méréseket, amelyek a digitális átállással, digitális eszközhasználattal kapcsolatban készültek az alábbi fókuszterületek valamelyikére vonatkozóan:

- gyermekkép,

- életvezetés,

- tanulási környezet,

- osztálytermi tevékenységek, tanulásszervezés és módszertan,

- tartalom-, tananyagközvetítés,

- tehetséggondozás és hátránykompenzáció,

- iskolai klientúra, családi háttér. 
Az összegzés célja a fellelt, a projektben is hasznositható kutatások egységes struktúrában, hasonló szempontok mentén történő bemutatása, ami:

- lehetővé teszi az adott témakör kapcsán kérdések megfogalmazását a fókuszcsoportos interjúk számára;

- azonosíthatóvá teszi az egyes kutatások, felmérések eszközeit, módszereit, ezáltal lehetőséget ad arra, hogy a későbbi tervezett online kutatás kérdöíve sztenderdizált módon, illetve más felmérésekkel összehasonlítható módon kerüljön összeállításra.

\section{Rövid elméleti kitekintés}

Mielőtt számba vesszük azokat a kutatásokat, amelyekről sikerült információt fellelnünk a fent jelzett területek vonatkozásában, néhány gondolat erejéig érdemes összefoglalóan áttekinteni a digitális eszközhasználattal kapcsolatos trendek közül azokat, amelyek az oktatás feltételrendszerét, tartalmi és módszertani kereteit is erőteljesen befolyásolják. Az OECD Trends Shaping Education 2016 c. kiadványának ötödik fejezetét a szakértők a technológiai fejlődés különböző aspektusainak szentelték, górcső alá véve azokat a változásokat, amelyek nemcsak mindennapi életünket formálják, hanem az iskolarendszerre, a tanulás különböző formáira is hatással vannak. A fiatal felnőttek és a gyerekek az online szolgáltatások és a közösségi hálók legintenzívebb használói, s az iskolának és a pedagógusoknak esetenként anélkül kellene segíteni öket az új eszközök használatában, bemutatni számukra a virtuális világ előnyeit és hátrányait, hogy maguk a pedagógusok rendelkeznének az ehhez szükséges ismeretekkel. Az új technológiák térhódításának időszakában bonyolult kérdések sora vetődik fel az oktatással összefüggésben. Így például az, hogy a tankönyvalapú tanulás képes-e felvenni a versenyt a modern technika azon előnyével szemben, amikor egyetlen gombnyomásra megkaphatjuk a választ a minket érdeklő kérdésekre. Vagy az a dilemma, hogy miként alkalmazkodjon az oktatási rendszer az olyan körülményekhez, mint a korábbinál rövidebb figyelmi idő, vagy a digitális eszközök túlzott használata kapcsán jelentkező elvonási tünetek. S ennél tágabban értelmezve a tanulási folyamatot vizsgálandó az is, hogy vajon megváltoztatja-e az emberi gondolkodást, a tanulási folyamatot - beleértve azt, hogy hogyan tároljuk és keressük vissza az információkat - a modern eszközök használata. (OECD, 2016)

Az internet- és számítógéphasználat ma már nem a kevesek kiváltsága, sőt, a modern társadalomban egyre inkább szükségszerüvé válik ezen eszközök használata a mindennapok során. Az intézmények, vállalatok és az egyének közötti kommunikáció, kereskedelem egyre nagyobb arányban zajlik az online 
térben: aki nem képes használni a modern eszközöket, könnyen hátrányba kerülhet, így például lemarad fontos tudnivalókról, vagy költségesebbé válik az élete. Kutatások azt mutatják, hogy a digitalizáció terén nemcsak az országok között, hanem az egyes országokon belül a népesség életkora és iskolázottsága szerint is óriásiak az eltérések. Nem feltétlenül az eszközökhöz való hozzáférésben, sokkal inkább a minőségi eszközhasználatban. Az informatikai jártasságnak pedig önmagában, más tényezőktől függetlenül is hatása van a munkakilátásokra, a keresetekre és az életminőségre, ilyen formában paradox módon a digitalizáció az egyenlőtlenségeket növelheti. (Hargittai, 2008) A modern technológiai eszközök használata tehát megköveteli, egyre fontosabbá teszi a fejlett informatikai készségek meglétét. Vajon hogyan állnak e téren a mai fiatalok és az őket tanító pedagógusok, milyen készségekkel és eszközhasználati szokásokkal rendelkeznek? Fontos kérdés az is, hogy mennyire tudatosan használják az informatikai eszközöket. S ami az oktatás tartalmi elemeit illeti: vajon az alapvető informatikai jártasságon túl szükségesek-e mélyebb ismeretek a tanulók körében, olyanok, amelyeket a közoktatásnak kell nyújtania minden tanuló számára. Szükséges-e például programozási vagy adatbázis-kezelési ismereteket tanítani mindenki számára, legyenek-e ezek is részei a kötelező tananyagnak, vagy elegendő az alapszintű felhasználó ismeretek átadása.

A továbbiakban e kérdések mentén hívjuk fel a figyelmet néhány nemzetközi kutatási eredményre, amelyek inspirációként szolgálhatnak a hazai kutatások megtervezéséhez. 


\section{Nemzetközi mérések a tanulók számítógépes és informatikai készségei, ismeretei kapesán}

\subsection{IEA International Computer and Information Literacy Study (ICILS 2013)}

Az informatikai képességeket leírni képes mutató kialakítását megalapozó mérés 60000 8. évfolyamos tanuló körében készült, 21 ország mintegy 3300 iskolájában. A tanulói tesztsort és kérdőívet mintegy 35000 pedagógus körében készült kérdőívvel, továbbá az iskolai rendszergazdák és az intézményvezetők körében készült felméréssel egészítették ki.

A tanulói CIL-teszt két készségterületre fókuszált, az egyik az információgyüjtés és- kezelés, míg a másik az információ létrehozása és cseréje. A feladatok négy különböző 30 perces modult jelentettek, s négy témakörhöz ${ }^{1}$ kapcsolódtak. A modulok közül kettőt kapott egy-egy tanuló, ily módon 6-féle kombinációja volt a tesztsoroknak, s egy tanuló 1 órát töltött a tesztekkel. A CIL-skálát a Rasch modell segítségével alakították ki, végeredményül egy 500 pontátlagú 100 szórású skálát készítettek. A tanulókat elért pontértékük szerint négy kategóriába sorolták be:

- 4-es szint (661 pont felett): magas szintü informatikai készségek, megfelelő szoftverhasználat, az információk megbízhatóságával kapcsolatos problémák tudatos kezelése;

- 3-as szint (577-661 pont): az információgyüjtés és -kezelés területén nagyfokú önállóság, megfelelő információforrások használata, az interneten elérhető információk megbízhatóságának felismerése;

- 2-es szint (492-576 pont): alapvető és explicit információk gyüjtése, kezelése, egyszerübb információk létrehozása, cseréje, személyes adatok védelme;

- 1-es szint (407-491 pont): funkcionális eszközhasználat, alapvető kommunikáció, szokásos szoftveres parancsok használata

Az egyes országok átlagértéke 361 és 553 között volt, Magyarország nem vett részt a vizsgálatban (lásd 1 . ábra).

\footnotetext{
${ }^{1}$ A modulok: 1. egy iskolán kívüli szabadidős program megszervezése, 2. iskola versenyhez weblap készítése, 3. egy prezentáció készítése, ami 8-9 éves gyerekeknek magyarázza el a légzés folyamatát, 4. iskolai kirándulás megtervezése (térképpel)
} 
Megalapozó háttértanulmány a digitális eszközök tanulási célú használatának vizsgálatához az osztálytermi tevékenységek, a tanulási környezet és a tanulói összetétel kontextusában

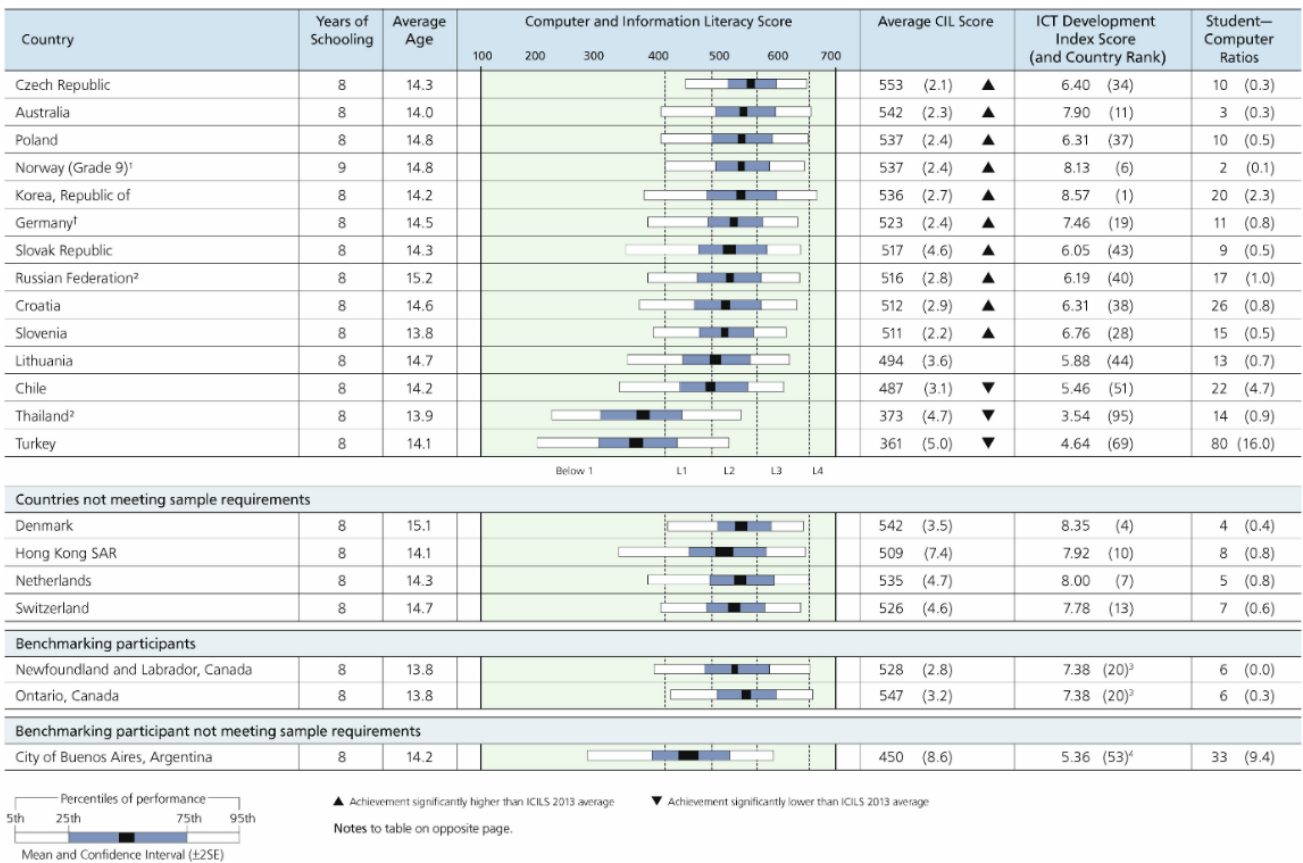

1. ábra A CIL-skála átlagértéke országonként

Az eredmények azt mutatták, hogy a CIL-index összefüggésben van a szocioökonómiai státusszal, mind az országon belül (tanuló szintjén), mind az országok között (országok fejlettsége). A lányok átlagos eredménye mindössze két országban jobb, mint a fiúké. A család szocioökonómiai státuszán kívül az otthoni IKT eszközellátottság (gépek száma, internet elérhetőség) is pozitív hatással volt az eredményekre, ugyanakkor ez a különbség eltünt, amikor a családi háttérre kontrollálták a modellt, ami arra utal, hogy a családi státusznak van nagyobb szerepe. Miután a teszt alapszintü informatikai készségeket mért, ezért a kifejezetten magas színvonalú informatikai jártasságnak (pl. programozni tudás, adatbáziskezelés) nem igazán volt szerepe a CIL-eredményekben, ugyanakkor a legtöbb országban megfigyelhető volt, hogy az informatika iránti érdeklődés, az informatikai eszközök kedvelése magasabb tesztpontszámokat eredményezett. Néhány országban statisztikailag szignifikáns összefüggést találtak az iskolai IKT eszközellátottság, az IKT-oktatás és a teszteredmények között, de - ahogy az más nemzetközi mérések esetében is kitünik - a legnagyobb szerepük itt is az otthoni hatásoknak van, ezen belül is leginkább a szocioökonómiai háttértényezőknek. (Fraillon et al., 2013)

A felmérés adatait használva később készült több elemzés is, így egy olyan, amelyik a pedagógusok illetve az iskolák IKT használati jellemzőit és a tanulók informatikai képességpontjait összevetve mélyebben vizsgálódott 4 ország 
(Ausztrália, Németország, Csehország, Norvégia) kapcsán. Az eredmények országonként (oktatási rendszerenként) jelentős eltéréseket tártak fel a tanulók CIL pontjai és a pedagógusok IKT eszközhasználati gyakorlata terén, bár arra nem volt mód, hogy a tanulói adatokat egyéni szinten összekapcsolják az őket tanító pedagógusok válaszaival. Ausztráliában az eszközellátottság is fontos szerepet játszott abban, hogy a pedagógusok használták-e az IKT eszközöket tanórán, míg a másik három országban ez az összefüggés nem jelentkezett. Az informatikai asszisztencia megléte egyedül Németországban volt pozitív hatással volt a tanórai IKT-eszközhasználatra. Ausztrália és Norvégia esetében a megfelelő informatikai továbbképzések megléte jelentős összefüggést mutatott azzal, hogy a pedagógusok használták-e az informatikai eszközöket a tanórán, de a legerősebb összefüggést az eszközhasználattal a tanári IK énhatékonyság, IKT kompetenciaérzet mutatta mind a négy országban. A legfontosabb tényezőnek tehát az mutatkozott, hogy a pedagógusok mennyire érezték magukat magabiztosnak az IKT eszközök használatában.(Gerick et al., 2017)

Az IKT énhatékonyság tekintetében egy másik tanulmány Csehország és Németország pedagógusait és tanulóit tovább vizsgálva azt találta, hogy a magasabb csehországi tanulói teszteredmények összefüggésben lehetnek azzal is, hogy Csehországban a pedagógusok jobban elkötelezettek az informatikai készségek fejlesztése terén és általában a szakmai továbbfejlődés irányában, amire több lehetőségük is van, s valószínüleg ennek is köszönhetően gyakrabban is használják az oktatásban a számítástechnikai eszközöket. (Drossel-Eickelman, 2017) 
1.1. táblázat: Az ICIL mérés főbb paraméterei

\begin{tabular}{|c|c|c|c|c|c|}
\hline $\begin{array}{l}\text { Kutatás/ } \\
\text { felmérés } \\
\text { neve }\end{array}$ & $\begin{array}{l}\text { Hatókör } \\
\text { (Regionális/ } \\
\text { Hazai/ } \\
\text { nemzetközi) }\end{array}$ & $\begin{array}{l}\text { Cél- } \\
\text { közönség } \\
\text { (Tanár/ } \\
\text { tanuló) }\end{array}$ & $\begin{array}{l}\text { Megje- } \\
\text { lenési } \\
\text { év }\end{array}$ & Típusa & $\begin{array}{l}\text { Elérhető, } \\
\text { nyilvános-e } \\
\text { a } \\
\text { mérőeszköz }\end{array}$ \\
\hline $\begin{array}{l}\text { IEA - } \\
\text { Internation } \\
\text { al Students } \\
\text { Computer } \\
\text { and } \\
\text { Informatio } \\
\text { n Literacy }\end{array}$ & nemzetközi & $\begin{array}{l}\text { elsődleges: } \\
\text { tanuló/ } \\
\text { másodlagos: } \\
\text { tanár }\end{array}$ & 2013 & 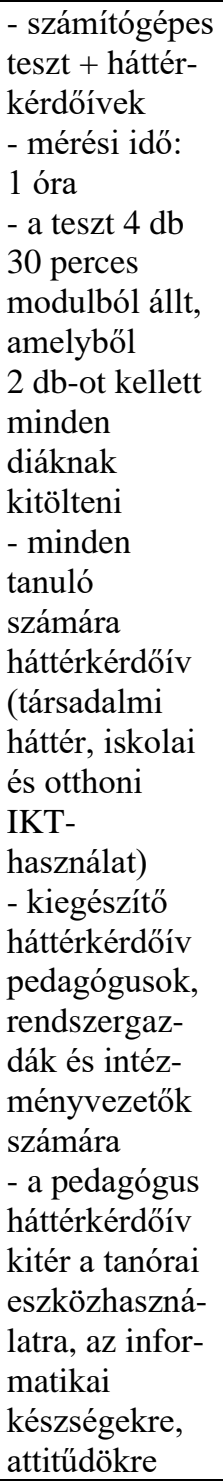 & Igen* \\
\hline
\end{tabular}

* A tesztekről csak mintafeladatok érhetők el, de a technikai jelentés tartalmazza a tanulói és a pedagógus háttérkérdőív jól használható kérdéseit is:

http://www.iea.nl/fileadmin/user_upload/Publications/Electronic_versions/ICIL S_2013_Technical_Report.pdf 


\subsection{Digitális PISA-mérés, 2012}

A PISA-program 2000-ben indult, s azóta háromévenként mérik a 15 évesek képességszintjét szövegértés, matematika és természettudomány területeken. A 2012. évi vizsgálat jelentős változást hozott abban a tekintetben, hogy már 32 ország állt át a számítógépes matematika, illetve a digitális szövegértés mérésére. A digitális mérésnek volt elözménye 2006-ban (természettudomány - 3 ország) és 2009-ben (szövegértés - 19 ország) is. A 2012. évi eredmények azt mutatták, hogy a matematika területén sok országban a számítógépes mérés eredményei rosszabbak lettek, mint a papíralapú teszteké, $\mathrm{s}$ a szövegértés esetében is ez volt a jellemzö, többek között Magyarországra is. A 2015. évi PISA eredmények hazánkban már csak ezért is szükségszerúen kedvezőtlenebbek a 2012. évihez képest, hiszen akkor már kizárólag digitális mérésre került sor. (Balázsi et al., 2013; PISA 2015; Ostorics et al., 2016)

A 2012. évi PISA mérésben az OECD országokban tanuló 15 évesek 96\%-a jelezte, hogy van otthon számítógépük, de csupán $72 \%$-uk használ legalább időnként számítógépet az iskolában. Ugyanakkor jó néhány jól teljesítő országban (pl. Korea, Sanghaj-Kína) az iskolai számítógéphasználat nagyon alacsony, mégis a digitálisan felvett tesztek eredménye is kiemelkedő. Az eredmények tehát egyrészt azt mutatják, hogy a modern IKT eszközök oktatásban való használata sok országban nem éri el a rendelkezésre álló lehetőségeket, ugyanakkor a felmérés eredményei nem egyértelmúek abban a tekintetben, hogy a modern eszközök használata valóban együtt jár-e a teszteredmények javulásával. (OECD, 2015).

A háttérkérdőív lehetőséget ad a tanórai IKT használat különböző jellemzőinek (pl. csak tanári vagy tanulói használat is, tantárgyak szerinti eltérések) a megkülönböztetésére, ezen kívül képet ad az eszközhasználat módjáról, a matematika tantárgy esetében a feladattípusokról stb., negatívuma azonban a felmérésnek, hogy erről csak a diákok illetve az intézményvezetők válaszai alapján kapunk némi képet, tehát nincs pedagógus kérdőív. Az IKT használat terén az összefoglaló elemzés alapvetően kétféle akadályt különít el: a hozzáférés (számítógépek, internet) hiányát és a pedagógiai szándék hiányát. Az előbbiek kapcsán az összefoglaló megállapítja, hogy a felszereltség mennyisége alapvetően nem, minősége viszont sokat javult az előző (2009. évi) PISA méréshez képest. 2012-re a tanulók 43\%-a fér hozzá iskolai laptophoz, s 11\%-uk tablethez, nem kis részben köszönhetően annak, hogy jelentős laptop-programok indultak néhány országban (pl. Ausztrália, Chile, Svédország). Az összefüggések arra is rámutatnak, hogy a pedagógusok IKT-eszközhasználata gyakoribb ott, ahol megfelelö képzést is kapnak ehhez a tanárok. Ugyanakkor az eszközhasználat alapvetően nem az iskolavezetésen, hanem magán az egyes pedagógusokon 
múlik: nagyobb eltérések vannak az egyes iskolákon belül, mint az egyes iskolák között. (OECD, 2015)

Az osztálytermi pedagógiai gyakorlatok közül a magas szintü IKT használat a tanulóorientált oktatási gyakorlattal és a formatív értékelési technikák gyakori használatával van leginkább összefüggésben, azaz azok a pedagógusok hajlamosabbak a tanórákon a digitális eszközök bevonására, akik tanulóorientált szemlélettel rendelkeznek, ugyanakkor ellentmondásosak az eredmények azzal kapcsolatban, hogy az informatikai eszközhasználat hogyan hat a tanulói fegyelemre. Valószínúleg itt ismét a tanári énhatékonyság-érzés lehet a háttérben: az alacsony szintü magabiztosság az eszközhasználatban, a kevésbé fejlett infokommunkációs készségek a pedagógusok körében könnyebben vezetnek valamiféle fegyelmezetlenségre az osztályteremben. (OECD, 2015)

Az iskolai számítógéphasználat és a teszteredmények összefüggését illetően egy speciális haranggörbe alakzat rajzolódott ki: a legmagasabb tesztpontszámokat azok a tanulók érték el, akik az átlagnál picit kevésbé intenzív iskolai számítógéphasználattal jellemezhetők. A számítógépet iskolában egyáltalán nem, vagy alig használók vagy csak néhány funkcióra használók összességében rosszabbul teljesítettek a teszten, mint ahogy azok is, akik nagyon intenzív és sokoldalú géphasználók. Ez utóbbira magyarázat lehet, hogy az intenzív eszközhasználat egy jelentős része a tanulás szempontjából nem produktív tevékenység (pl. chat), vagy a fö funkciója a „drillezés”, a feladatok gyakoroltatása, ami úgy tünik, hogy a képességtesztek eredményeire nincs pozitív hatással. A különféle tevékenységek közül az internetes kereséshez kötődő feladatok megfelelő gyakoriságú - heti 1-2 alkalom - alkalmazása mutatott a leginkább pozitív kapcsolatot a teszteredményekkel. (OECD, 2015)

A felmérés adatai lehetőséget adnak a szocioökonómiai státusz szerinti adatelemzésre is. Ezekből az rajzolódik ki, hogy a minőségi eszközökhöz való hozzáférés (pl. otthoni számítógépek száma, mobileszközök, WiFi elérhetősége stb.) jelentős eltérések vannak a hátrányos helyzetü és a magasabb státuszú tanulók között. Ugyancsak jelentős eltérések mutatkoznak abban szociális státusz szerint, hogy a tanuló hány éves korában találkozott először számítógéppel, $\mathrm{s}$ milyen szinten, milyen feladatokhoz (pl. közösségi oldalak felkeresése, hírolvasás, online ügyintézés) képes azt a mindennapokban használni.

Mindezek alapján fontos kutatási kérdés, hogy - bár látszólag minden tanuló kezében ott az okostelefon, s a legtöbb családban van otthoni számítógép - az oktatásba ezek mennyire vonhatók be. Hogyan képes kezelni az oktatási rendszer azokat az esélykülönbségeket, amelyek az otthoni eszközök eltérő minőségéből, illetve az informatikai eszközök használatának eltérő „szocializációjából” és az 
informatikai készségek eltérő fejlettségéből fakadnak, s miként lehet segíteni a pedagógusokat a tanulási folyamat irányításában.

1.2. táblázat: A PISA 2012 mérés főbb paraméterei

\begin{tabular}{|c|c|c|c|c|c|}
\hline $\begin{array}{l}\text { Kutatás/ } \\
\text { felmérés } \\
\text { neve }\end{array}$ & $\begin{array}{l}\text { Hatókör } \\
\text { (Regionális/ } \\
\text { Hazai/ } \\
\text { nemzetközi) }\end{array}$ & $\begin{array}{l}\text { Célközönség } \\
\text { (Tanár/ } \\
\text { tanuló) }\end{array}$ & $\begin{array}{l}\text { Megje- } \\
\text { lenési } \\
\text { év }\end{array}$ & Típusa & $\begin{array}{l}\text { Elérhető, } \\
\text { nyilvános-e } \\
\text { a } \\
\text { mérőeszköz }\end{array}$ \\
\hline $\begin{array}{l}\text { OECD - } \\
\text { PISA }\end{array}$ & nemzetközi & tanuló & 2012 & $\begin{array}{l}\text { - számítógépes } \\
\text { teszt + háttér- } \\
\text { kérdőívek } \\
\text { - minden } \\
\text { tanuló } \\
\text { számára } \\
\text { háttérkérdőív } \\
\text { (társadalmi } \\
\text { háttér, iskolai } \\
\text { és otthoni } \\
\text { IKT- } \\
\text { használat) } \\
\text { - kiegészítő } \\
\text { háttérkérdőív } \\
\text { intézményve- } \\
\text { zetők számára } \\
\text { - kiegészítő } \\
\text { háttérkérdőív } \\
\text { szülők } \\
\text { számára }\end{array}$ & Igen* \\
\hline
\end{tabular}

* A kérdőívek elérhetősége:

http://www.oecd.org/pisa/pisaproducts/pisa2012database-downloadabledata.htm

\subsection{TIMSS 2011}

Az IEA rendszeres mérései közé tartozik a négyévente lebonyolított TIMSSmérés, amelynek célja a 4. és 8. évfolyamos tanulók teljesítményének vizsgálata a matematika és a természettudományok területén. A TIMSS tehát nem képességeket, hanem sokkal inkább tananyagtartalmakat és ahhoz kapcsolódó teljesítményeket mér. A felmérés fontos részét képezi háttéradatok gyüjtése mind a pedagógusoktól, mind az iskolavezetéstől, így például a tantervi tartalmakról, a pedagógusok felkészültségéről, tanítási gyakorlatáról. Bár 2015-ben volt az utolsó 
felmérés, a 2011. évi felmérés kapcsán született néhány olyan elemzés, amelyet érdemesnek tartunk bemutatni.

A 2011. évi adatok azt mutatják, hogy az iskolákban jelentősen nőtt a hozzáférés a korszerü informatikai eszközökhöz, a matematikaórákon a nyolcadikos tanulók csaknem fele, természetismeret órákon pedig valamivel több mint fele már 2011ben is képes volt elviekben a számítógéphasználatra, azaz olyan teremben tanult, ahol legalább egy számítógép volt. Ez az összes OECD országra vonatkozó érték, amely Magyarországon valamivel alacsonyabb, mintegy 40\%-os arányt mutat. Az internetelérési lehetőségeket ugyanez jellemezte Magyarországon: dinamikus növekedés 2003-hoz képest, de még mindig nagyon alacsony hozzáférés 2011ben is. Megfigyelhető volt, hogy a negyedikesek osztálytermei kevésbé felszereltek, mint a nyolcadikosoké. (OECD, 2014)

Mindezek alapján nem meglepö, hogy a tanórai számítógéphasználat alacsonyabb értéket mutat Magyarországon, mint az OECD-átlag, különösen negyedik évfolyamon. Itt a legalább időnként számítógépet használó tanulók aránya alig egynegyed, míg Angliában, Belgiumban, Dániában vagy Szingapúrban a negyedikesek több mint fele legalább időnként használ számítógépet természetismeret vagy matematika tanórán. A tanórai számítógéphasználat a legtöbb országban leginkább az információszerzésre, ötletek gyüjtésére terjed ki, jóllehet sok országban a diákok a számítógépeket adatelemzéshez, tudományos kísérletek végzésére, vagy a természeti jelenségek megfigyelésének szimulációjára is használják. Magyarországon ez utóbbiak kevésbé elterjedtek, még e területen az időnkénti használat ${ }^{2}$ is igen alacsony értéket mutat. (OECD, 2014)

A TIMSS-felmérés teszteredményei és a tanórai számítógéphasználat összefüggése nem egyértelmü a jelentés írói szerint, jórészt azért, mert az eredmények a társadalmi háttérrel és a tanítási gyakorlattal is összefüggésben vannak. A felmérés adatai mindenesetre azt mutatták, hogy a negyedik évfolyamos tanulók eredményei pozitívan korreláltak a tanórai számítógéphasználattal. (Mullis et al., 2013)

Több összefoglaló jelentés is készült, amelyek a nemzetközi mérések (PISA, TIMMS) teljesítménymutatóit és a számítógéphasználat jellemzőit kívánták összefüggéseiben feltárni (pl. Eickelmann et al, 2017; Bulman - Fairlie, 2016). Jellemzően nem találtak egyértelmü lineáris ok-okozati kapcsolatot. Hettie 2013ban az utóbbi 30 év kutatásainak metaanalízisét elvégezve arra jutott, hogy a

\footnotetext{
${ }^{2}$ A pedagógusok a tanulók különböző célú számítógéphasználatát az alábbi gyakorisági skálán jelölhették: Mindennap vagy majdnem mindennap, Hetente egyszer-kétszer; Havonta egyszer-kétszer; Soha vagy majdnem soha.
} 
számítógéppel támogatott tanítás (computer-assisted instruction - CAI) hatása nem nagyobb vagy nem kisebb más tanítási módoknál, feltéve, hogy azokat jól tervezik meg. Hattie és Yates (2013) könyvükben arra mutatnak rá, hogy a számítógépek pozitív hatása erősebb akkor, amikor kiegészítő szerepet szánnak neki az oktatásban, például amikor a tanulási idő megnöveléséről van szó (pl. plusz oktatás, gyakorlás), vagy amikor a tanulók önálló tanulásvezérléséhez, illetve a csoportos tanulás támogatásához használják.

A TIMSS-adatok mélyebb elemzését Falck, Mang és Woessmann végezték el, akik rámutattak az összefüggések nem lineáris természetére és azok összetettségére. Tanulmányukban abból indultak ki, hogy a kutatások jelentős része nem talált összefüggést a tanórai számítógéphasználat és a tanulói teljesítmény között. Elemzésükhöz a 2011. évi TIMSS adatokat használták és elméletüket egy közgazdasági modellre, a határhaszon elméletre építették. Abból indultak ki, hogy a tanóra minden percét különféle aktivitásokra lehet használni, amelyek közül van, amelyik jobban, más pedig kevésbé járul hozzá a teljesítménynövekedéshez. A számítógéphasználat bizonyos tevékenységek (pl. ötletek, információk keresése) esetében időfelhasználás szempontjából verhetetlen alternatívának tűnik, míg más esetekben a számítógéppel támogatott tanulás nem hoz időmegtakarítást, vagy esetleg a hagyományos tanítási formák jobb pedagógiai eredménnyel kecsegtetnek. Eredményeik azt mutatják, hogy helytálló volt a hipotézisük: a matematika eredmények pozitív összefüggést mutatnak azzal, ha a tanórai számítógéphasználat elsősorban az új ötletek, információk keresését helyezi fókuszba, és negatív összefüggés látszik azzal, ha a feladatgyakorlás áll a használat középpontjában. A tanulók egyes alcsoportjait is megvizsgálva a nemek és az otthoni számítógéphasználat szerint nem mutatkozott eltérés a hatásokban, viszont a társadalmi háttér szerint igen: a jobb képességüek esetében a hatások még nagyobbak voltak. (Falck-Mang-Woessmann, 2018)

Mindezek a kutatások, elemzések szakpolitikai szempontból is kihívást jelentenek és kérdéseket vetnek fel, hiszen az iskolák informatikai eszközökkel való felszerelése, azok folyamatos modernizálása és a pedagógusok felkészítése ezen eszközök használatára sok pénzbe kerül. Nem mindegy tehát az eszközök használata, továbbá az sem mindegy, hogy hogyan állítható az az esélyegyenlőség szolgálatába. 
1.3. táblázat: A TIMSS 2011 mérés főbb paraméterei

\begin{tabular}{|c|c|c|c|c|c|}
\hline $\begin{array}{l}\text { Kutatás/ } \\
\text { felmérés } \\
\text { neve }\end{array}$ & $\begin{array}{l}\text { Hatókör } \\
\text { (Regionális/ } \\
\text { Hazai/ } \\
\text { nemzetközi) }\end{array}$ & $\begin{array}{l}\text { Célközönség } \\
\text { (Tanár/ } \\
\text { tanuló) }\end{array}$ & $\begin{array}{l}\text { Megje- } \\
\text { lenési } \\
\text { év }\end{array}$ & Típusa & $\begin{array}{l}\text { Elérhető, } \\
\text { nyilvános-e } \\
\text { a } \\
\text { mérőeszköz }\end{array}$ \\
\hline $\begin{array}{l}\text { TIMSS, } \\
2011\end{array}$ & nemzetközi & $\begin{array}{l}\text { elsődleges: } \\
\text { tanuló, } \\
\text { másodlagos: } \\
\text { iskola, } \\
\text { pedagógus }\end{array}$ & 2011 & $\begin{array}{l}\text { - tanulói } \\
\text { tudásszint- } \\
\text { mérés 4. és } 8 . \\
\text { osztályban } \\
\text { matematika és } \\
\text { természettu- } \\
\text { domány } \\
\text { területeken } \\
\text { - kiegészítő } \\
\text { háttér-kérdőív } \\
\text { intézmények, } \\
\text { pedagógusok } \\
\text { számára } \\
\text { - tantervi } \\
\text { elemeket } \\
\text { rögzítő } \\
\text { kérdőív }\end{array}$ & igen* \\
\hline
\end{tabular}

* A kérdőívek elérhetősége:

https://timssandpirls.bc.edu/timss2011/international-contextual-q.html

\section{A nemzetközi mérések tanulságai}

Az elözőekben áttekintett vizsgálatok közös jellemzője, hogy alapvetően a tanulók a célcsoportja, az ő teljesítményüket, eszközhasználatukat, kompetenciáikat vizsgálja (az ICL szigorúan véve az informatikai területen, míg a másik két felmérés az egyes tantárgyakhoz, képességterületekhez kapcsolódóan), ugyanakkor mindhárom felmérés közvetetten a pedagógusok IKT használatáról, a pedagógiai munka különböző aspektusairól is információkkal szolgál. Az adatok arra mutatnak, hogy az IKT eszközhasználat és a tanulási teljesítmény között nem lineáris, illetve ambivalens az összefüggés, esetenként a hatások kioltják egymást. A hatásokat tehát érdemes részleteiben is megvizsgálni, továbbá nagyon fontos a pedagógusok eszközhasználati kompetenciáinak, az infokommunikációs technológiai eszközök használatával kapcsolatos énhatékonyságnak a javítása. Önmagában az eszközellátottság növelése nem feltétlenül jár együtt sem a tanulói teljesítmények javulásával, sem a pedagógusok eszközhasználati gyakoriságának emelkedésével. 


\section{Irodalom:}

1. Balázsi Ildikó, Ostorics László, Szalay Balázs, Szepesi Ildikó, Vadász Csaba (2013): PISA 2012. Összefoglaló jelentés. Oktatási Hivatal, Budapest

2. Bulman, George - Fairlie, Robert W. (2016): Technology and Education: Computers, Software, and The Internet. Working Paper 22237. National Bureau of Economic Research, Cambridge, MA http://www.nber.org/papers/w22237

3. Drossel, Kerstin - Eickelmann, Birgit (2017): Teachers' participation in professional development concerning the implementation of new technologies in class: a latent class analysis of teachers and the relationship with the use of computers, ICT self-efficacy and emphasis on teaching ICT skills. In: Large-scale Assessments in Education, An IEA-ETS Research Institute Journal. Vol. 5, Article 19.

4. Eickelmann, Birgit - Gerick, Julia - Koop, Christian (2017): ICT use in mathematics lessons and the mathematics achievement of secondary school students by international comparison: Which role do school level factors play?,Education and Information Technologies, 22, 4,(1527)

5. Falck, Oliver - Mang, Constantin and Woessmann, Ludger (2018): Virtually No Effect? Different Uses of Classroom Computers and their Effect on Student Achievement, Oxford Bulletin of Economics an Statistics, 80, 1 (2018) 0305-9049

6. Fraillon, Julian - Ainley, John - Schulz, Wolfram - Friedman, Tim Gebhardt, Eveline (2013): Preparing for Life in a Digital Age. The IEA International Computer and Information Literacy Study. International Report. IEA - Springer Online

7. Gerick, Julia - Eickelmann, Birgit - Bos, Wilfried (2017): Schoollevel predictors for the use of ICT in schools and students' CIL in international comparison. In: Large-scale Assessments in Education, An IEA-ETS Research Institute Journal. Vol. 5, Article 5 .

8. Hargittai, Eszter (2008): The Digital Reproduction of Inequality. In: David B. Grusky (ed.): Social Stratification.Westview Press 936-944. 
9. Hattie, John (2013): Visible learning: A synthesis of over 800 metaanalyses relating to achievement, Routledge, Abingdon

10. Hattie, John - Yates, Gregory (2014): Visible learning and the science of how we learn, Routledge, Abingdon

11. Mullis, Ina V.S. - Martin, Michael O. - Foy, Pierre - Arora, Alka (2013): TIMSS 2011 International Results in Mathematics. TIMSS \& PIRLS International Study Center- IEA, Chestnut Hill-Amsterdam

12. OECD (2014): Measuring Innovation in Education: A New Perspective, Educational Research and Innovation, OECD Publishing. http://dx.doi.org/10.1787/9789264215696-en

13. OECD (2016): Trends shaping Education 2016, OECD Publishing, Paris.

14. OECD (2015): Students, Computers and Learning: Making the Connection, PISA, OECD Publishing.

15. Ostorics László, Szalay Balázs, Szepesi Ildikó, Vadász Csaba (2016): PISA 2015. Összefoglaló jelentés. Oktatási Hivatal, Budapest 